\title{
a infância e o (in)dizível: poder ubuesco, resistência e a possibilidade da justiça
}

\author{
eduardo rezende melo ${ }^{1}$ \\ universidade de são paulo, são paulo, brasil \\ orcid id: https:/ / orcid.org/0000-0003-3779-1814 \\ flavia schilling 2 \\ universidade de são paulo, são paulo, brasil \\ orcid id: https:/ / orcid.org/0000-0001-5126-8507
}

\section{resumo}

O artigo, como parte de uma reflexão mais ampla em torno da crítica ao direito ao desenvolvimento e seu impacto nos modos de subjetivação jurídico-política de crianças e adolescentes, problematiza a condição da criança como sujeito sem fala, ou uma fala condicionada a critérios de maturação, ditados pelo referencial adulto, num campo, ademais, delimitado ao que se lhes repute pertinente à sua manifestação. Pautado pelo pensamento da exterioridade, retomamos o debate foucaultiano sobre a pertinência entre verdade e justiça, particularmente da indizibilidade monstruosa das práticas jurídicas e judiciárias, a partir da descrição ubuesca deste poder. Em transposições críticas, analisaremos, pelas contribuições do cinismo clássico (kynismos), apoiados em Foucault, Sloterdijk, Nieheus-Pröbsting, as práticas resistentes - para além da linguagem- de crianças e adolescentes. Tratar-se-á, assim, de colocar a (in)dizibilidade no centro das disputas de poder para nos abrirmos, com Derrida, Rancière, Butler e também Foucault, a repensarmos vulnerabilidades, direitos humanos e a possiblidade da justiça. O texto se desenvolverá com os seguintes eixos de análise:1. Contextualizando o debate foucaultiano sobre verdade e justiça e o lugar do dizível; 2. A (in)dizibilidade no cerne do direito, da infância e da monstruosidade; 3. Poder ubuesco e resistência kynica;e 4. Para concluir: a criança e a possibilidade da justiça.

palavras-chave: infância; verdade; resistência; kynismos; direitos humanos; justiça.

\section{la infancia y lo (in)decible: poder ubuesco, resistencia y la posibilidad de la justicia}

\section{resumen}

El artículo, como parte de una reflexión más amplia en torno a la crítica del derecho al desarrollo y su impacto en los modos de subjetivación jurídico-política de los y las niñas y adolescentes, problematiza la condición del niños como sujeto sin habla, o un habla condicionada a criterios de maduración, dictados por el referencial adulto, en un campo, además, delimitado a lo que se aprecie pertinente en su manifestación. Pautado por el pensamiento de la exterioridad, retomamos el debate foucaultiano sobre la pertinencia entre verdad y justicia, particularmente de la indecibilidad monstruosa de las prácticas jurídicas y judiciales, a partir de la descripción ubuesca de este poder. En transposiciones críticas, analizaremos, a través de las contribuciones del cinismo clásico (kynismos), apoyados en Foucault, Sloterdijk, Nieheus-Pröbsting, las prácticas resistentes -más allá del lenguaje- de niños, niñas y adolescentes. Se tratará, así, de colocar la (in)decibilidad en el centro de las disputas de poder para abrirnos, con Derrida, Rancière, Butler y también Foucault, a repensar vulnerabilidades, derechos humanos y la posibilidad de la justicia. El

\footnotetext{
1 Email: melo.eduardorezende@gmail.com

2 Email: flaviaischilling@gmail.com
} 
a infância e o (in)dizível: poder ubuesco, resistência e a possibilidade da justiça

texto se desenvolverá con los siguientes ejes de análisis: 1. Contextualizando el debate foucaultiano sobre verdad y justicia y el lugar de lo decible; 2 . La (in)decibilidad en el corazón del derecho, de la infancia y de la monstruosidad; 3. Poder ubuesco y resistencia kynica; 4. Para concluir: el niño y la posibilidad de la justicia.

palabras clave: infancia; verdad; resistencia; kynismos; derechos humanos; justicia.

\section{childhood and the (un)speakable: ubuesco power, resistance, and the possibility of justice}

abstract

The article, as part of a broader reflection on the criticism of the right to development and its impact on the modes of legal and political subjectivation of children and adolescents, questions the child's condition as a subject without speech, or a speech conditioned to criteria of maturation, dictated by the adult referential, in a field, moreover, limited to what is said to be pertinent to their manifestation. Guided by the thought of exteriority, we return to the Foucauldian debate on the relation between truth and justice, in light of the monstrous unspeakability of legal and judicial practices and the ubuesco of state power. We will analyze, through the contributions of classic cynicism (kynismos), supported by Foucault, and Sloterdijk, Nieheus-Pröbsting, the resistant practices - beyond language available to children and adolescents, and rethink these power struggles in the context of human rights and the possibility of justice, through the thought of Derrida, Rancière, Butler and Foucault. Our text will develop along the following axes of analysis: 1. Contextualizing the Foucaultian debate on truth and justice and the place of the "sayable"; 2. Considering the (in)sayability at the heart of law, childhood and monstrosity; 3. Framing the struggle between ubuesco power and cynic resistance, and 4. Speculating on our notions of "child" and the possibility of justice.

keywords: childhood; truth; resistence; kynismos; human rights; justice. 
a infância e o (in)dizível: poder ubuesco, resistência e a possibilidade da justiça

Este artigo insere-se numa reflexão mais ampla em torno da arqueologia do direito do desenvolvimento como dispositivo na subjetivação jurídico-política de crianças e adolescentes e as contribuições críticas da filosofia contemporânea a este debate (Melo, prelo) ${ }^{3}$.

O modo de regramento e de interpretação do direito ao desenvolvimento, reconhecido como princípio do direito da infância, pauta-se por uma naturalização acrítica, embora perpasse diversas dimensões de vida sociopolítica de crianças e adolescentes e a despeito de ser o desenvolvimento tema atravessado por polêmicas em distintas áreas do saber.

A promessa dos novos marcos normativos mostra-se vã: o reconhecimento de crianças e adolescentes como sujeitos de direitos é insuficiente para superar arranjos político-institucionais e associações interdisciplinares em torno do direito (Donzelot, 1986; Platt, 1974; Rizzini, 1993; Costa, 1999) que faziam da infância o lócus privilegiado de controle e normalização. Aquilo que poderia expressar-se em termos de agência converte-se, quando muito, em manifestações de participação administrada, pensadas fundamentalmente em termos evolutivos da capacidade das crianças e adolescentes - uma noção intimamente tributária de uma certa leitura do que seja desenvolvimento, particularmente psicológico. Neste contexto, a criança remanesce sujeito sem fala, ou uma fala condicionada a critérios de maturação, pautados pelo referencial adulto, num campo, ademais, delimitado ao que se lhes repute pertinente à sua manifestação.

Problematizar o direito ao desenvolvimento implicou, assim, dentre vários outros temas, questionar os pressupostos jurídicos, políticos, filosóficos, os contextos sociais e também políticos da possibilidade de fala, do seu reconhecimento como voz, e não como ruído. Implicou, portanto, deslocar a leitura do tema da participação para refletir as dimensões de poder inerentes a uma reflexão do desenvolvimento como "direito" e, com elas, os modos de subjetivação de crianças e adolescentes.

\footnotetext{
${ }^{3}$ A obra é fruto de tese de doutorado defendida no programa de direitos humanos da Faculdade de Direito da USP, sob orientação da Professora Doutora Flávia Inês Schilling.
} 
a infância e o (in)dizível: poder ubuesco, resistência e a possibilidade da justiça

Procuramos, então, pautados pelo pensamento de Michel Foucault e outros pensadores, realizar uma arqueologia do discurso e do objeto "desenvolvimento" quando relacionado ao direito. Neste exercício crítico pautado pelo pensamento pela exterioridade, procuramos analisar também a função deste direito em relação não apenas a crianças e adolescentes, mas a todos nós: como este discurso e esse objeto se expressam nas práticas jurídicas e judiciárias incidentes nos corpos e vidas de crianças e adolescentes em nome de seu "direito ao desenvolvimento".

Aqui, pretendemos retomar este pensamento da exterioridade em relação às instituições, com enfoque no debate foucaultiano sobre a pertinência entre verdade e justiça. Tomaremos como cerne da análise a reflexão em torno da indizibilidade monstruosa das práticas jurídicas e judiciárias a partir da descrição ubuesca deste poder por Michel Foucault, mas também de Donzelot e outros autores. Em seguida, em transposições críticas, analisaremos, a partir das contribuições do cinismo clássico $\left(\right.$ kynismos $\left.^{4}\right)$, apoiados em Foucault, Sloterdijk e outros, as práticas resistentes, para além da linguagem, de crianças e adolescentes. Tratar-se-á, assim, de colocar a (in)dizibilidade no centro das disputas de poder para nos abrirmos, com Derrida, Rancière, Butler e também Foucault, a repensarmos vulnerabilidades, direitos humanos e a possiblidade da justiça.

O texto se desenvolverá, portanto, com os seguintes eixos de análise:

1. Contextualizando o debate foucaultiano sobre verdade e justiça e o lugar do dizível;

2. A (in)dizibilidade no cerne do direito, da infância e da monstruosidade;

3. Poder ubuesco e resistência kynica;

4. Para concluir: a criança e a possibilidade da justiça.

contextualizando o debate foucaultiano sobre verdade e justiça e o lugar do dizível

O tema da dizibilidade, embora não particularmente explicitado, perpassa as análises foucaultianas em torno da pertinência entre verdade e justiça. Para que

\footnotetext{
${ }^{4}$ Nieues-Pröbsting e Sloterdijk valem-se do termo kynismos, referido particularmente à figura de Diógenes, para distingui-lo do cinismo moderno. Neste ensaio, a referência será sempre ao kynismos antigo (NIEUES-PRÖBSTING, 2016; SLOTERDIJK, 2012)
} 
possamos compreender a dimensão da transposição proposta em suas obras finais, parece-nos importante contextualizar brevemente como se colocam nas anteriores.

O tema ganha corpo na obra foucaultiana em "A verdade e as formas jurídicas", um seminário que se tornou clássico. Foucault indagava-se ali sobre como se puderam formar domínios de saber a partir de práticas sociais, que não somente fazem aparecer novos objetos, novos conceitos, novas técnicas, mas também fazem nascer formas totalmente novas de sujeitos e de sujeitos de conhecimento. As práticas jurídicas e as judiciárias parecem-lhe campos privilegiados de análise das relações entre homem e verdade e, neste contexto, da própria historicidade do sujeito de conhecimento (Foucault, 1996, 7-11).

Foucault retoma o mito de Édipo, tendo presente a crítica já desenvolvida por Deleuze e Guattari, para enfatizar seu caráter de instrumento de poder, não apenas num nível individual, como também coletivo, mas também de poder e de saber (Foucault, 1996, 31). Para o filósofo, Édipo está na base do advento de um novo modelo de pesquisa de verdade no âmbito judiciário, superando o procedimento judiciário (grego), recuperado no direito feudal ${ }^{5}$, ou as provas de tipo profético e prescritivo. Para o pensador francês, Édipo representa um modelo de pesquisa retrospectiva da verdade, da ordem do testemunho (Foucault, 1996, 40), portanto do dizível. O inquérito, para Foucault, é precisamente uma forma política de autenticar a verdade, portanto uma forma de saber-poder (Foucault, 1996, 78), enevoado pelo grande mito ocidental platônico de que a verdade nunca pertence ao poder político, mais ainda, de que haveria uma antinomia entre saber e poder (Foucault,1996, 50-51).

Deste mito - tão fundamental quando se pensa a infância na psicanálise - e deste modo de perquirição de verdade, desdobram-se um novo modelo, no século XVIII e início do século XIX, quando se constitui a sociedade disciplinar e, com ela, uma função não mais de punir as infrações dos indivíduos, mas de corrigir suas virtualidades: o do exame e da vigilância (Foucault, 1996, 86-88).

\footnotetext{
${ }^{5}$ Foucault lembra, com base na Ilíada, que o procedimento judiciário grego era uma espécie de jogo, de prova, uma maneira regulamentada de fazer a guerra, como uma maneira de provar não a verdade, mas a força, o peso, a importância de quem dizia (FOUCAULT, 1996, 55-62)
} 
a infância e o (in)dizível: poder ubuesco, resistência e a possibilidade da justiça

Emerge toda uma série das instituições de vigilância que tem por finalidade não excluir, mas, ao contrário, fixar os indivíduos, tendo o poder judiciário como referência. Assim, o sistema escolar, tal como o poder judiciário, pune e recompensa, avalia, classifica, diz quem é o melhor, quem é o pior. É a estrutura de vigilância que, chamando para si os indivíduos, tomando-os individualmente, integrando-os, vai constitui-los secundariamente enquanto grupo (Foucault, 1996, 113-115).

Como ensina Ewald, o advento da norma implica um outro tipo de pertinência entre verdade e justiça. No começo do século XIX há duas grandes objetivações concorrentes da sociedade, tendo ambas as mesmas pretensões de constituir a ciência do homem, dar estatuto científico ao conhecimento da sociedade, a fundar a "física social" ou a "sociologia": Comte e Quételet. É com Quételet e sua aplicação da teoria matemática das chances ao estudo dos fenômenos sociais, objetivando-os de forma estatístico-probabilística (Ewald, 1986, 3873-3894), que advirá o novo modelo.

Com a teoria do homem médio, Quételet propõe um modo de individualização dos indivíduos não mais a partir de si mesmos, do que seria sua natureza ou do que deveria ser seu ideal, mas a partir do grupo ao qual eles pertencem. Ela permite referir uma população, uma coletividade e os indivíduos que a compõem não mais a algo de exterior, a uma finalidade, mas a si mesma. Diferentemente da normalização disciplinar, clássica, pela qual os indivíduos não são identificados e julgados por referência a uma média, mas por uma norma, uma regra, uma escala que lhes é exterior do melhor ao bom, do perfeito ao execrável, a normalização ligada ao homem médio seria de outro tipo: parte-se da massa, da própria coletividade e é em função de sua normalidade que se efetua a classificação, não em ordem hierárquica, mas por separação com relação a uma média que não indica o mínimo a atingir, mas o tipo do grupo (Ewald, 1986, 4248-4294).

É em função dessa técnica de individualização e diferenciação do grupo com relação a si mesmo, em função da ideia de norma ou de média, que opera a tecnologia do risco como modo geral de gestão das populações: ela serve para definir as normas e para localizar os distanciamentos agora identificados como 
'riscos. Risco significa agora 'anormalidade', 'inadaptação': o anormal será aquele que, afastando-se muito da norma, distanciando-se de modo que seu caso se singularize, torna-se um risco para o grupo, um perigo (no sentido largo de problema, de dificuldade, de ameaça), tornando-se necessária a tomada de procedimentos de identificação preventivos para que não se chegue ao ato, não se torne verdadeiramente perigoso (Ewald, 1986, 11553-11602).

\section{a (in)dizibilidade no cerne do direito, da infância e da monstruosidade}

Vimos como Foucault tratou inicialmente o tema da pertinência entre verdade e justiça: a passagem de um modelo estruturado em torno de uma verdade dizível, retrospectivamente buscada pelo testemunho, no âmbito do inquérito, para uma verdade construída a partir da técnica de individualização e de diferenciação das médias sociais, tomadas como normativas e disciplinares do bom funcionamento social. Um deslocamento, portanto, do dizível relativo unicamente ao discurso para um dizível que tem como objeto práticas sociais.

Aqui trataremos de um deslocamento operado por Michel Foucault em seu curso sobre "Os anormais", analisando esse tema da pertinência entre verdade e justiça pela sua exterioridade anormal, a partir de uma das figuras estudadas, o incorrigível. E o fazemos porque, mais até que em seus congêneres (a criança onanista ou o monstro delinquente, analisados com mais detalhamento nesse curso), é nesta modalidade que emerge com mais clareza o aspecto fundamental que pretendemos analisar na relação entre verdade, justiça e infância: a (in)dizibilidade, que reputamos como um dos elementos centrais da monstruosidade enquanto princípio de inteligibilidade de todas as formas da anomalia (Foucault, 2014, 48-49).

O indivíduo a ser corrigido tem como contexto de referência a família mesma, no exercício de seu poder interno ou na gestão de sua economia; ou, no máximo, a referência é a família em sua relação com as instituições que lhe são vizinhas ou que a apoiam ${ }^{6}$. O indivíduo a ser corrigido vai aparecer nesse sistema de apoio que

\footnotetext{
${ }^{6} \mathrm{O}$ filósofo sustenta no curso antecedente, sobre "O poder psiquiátrico", ter sido em razão do poder de soberania da família que crianças e adolescentes e as pessoas com deficiência tiveram lugar central no exercício do poder disciplinar, pois, como um resto e uma espécie de célula no interior da qual o
} 
a infância e o (in)dizível: poder ubuesco, resistência e a possibilidade da justiça

existe entre a família, e, depois, a escola, a oficina, a rua, o bairro, a paróquia, a igreja, a polícia, etc. e tem outra diferença em relação ao monstro: sua taxa de frequência é muito mais elevada. $\mathrm{O}$ monstro é, por definição, uma exceção. $\mathrm{O}$ indivíduo a ser corrigido é um fenômeno corrente e, de tão corrente, o fenômeno que tem a característica paradoxal de ser regular na sua irregularidade, tornando mais difícil determiná-lo. Ele está, para Foucault, no exato limite da indizibilidade (Foucault, 2014, 49).

É esta indizibilidade decorrente de sua indeterminação que nos parece central na análise foucaultiana, porque aponta a tautologia operatória de se definir um indivíduo a ser corrigido por sua incorrigibilidade, numa espécie de jogo sempiterno entre incorrigibilidade e corrigibilidade (Foucault, 2014, 49-50).

Embora Foucault não aprofunde aparentemente esta figura do incorrigível, ele deixa claro que a característica fundamental do indivíduo a ser corrigido, sua recorrência e disseminação incidindo em diversos campos sociais, deu-se por intermédio da infância. Foi a infância que permitiu a passagem da grande monstruosidade, do monstro-rei-político, numa divisão e distribuição em várias pequenas anomalias, de personagens que são ao mesmo tempo anormais e familiares, com base nas pequenas perversidades, maldades infantis; portanto, a passagem do monstro ao anormal (Foucault, 2014, 93-94).

Foi pelo problema da hereditariedade e pela correção e normalização da economia dos instintos, pela psicanálise (Foucault, 2014, 114), que o psiquiatra se torna agente dos perigos intrafamiliares no que eles podem ter de mais cotidiano, inscrevendo-se a psiquiatria como técnica de correção, mas também de restituição do que poderíamos chamar de justiça imanente das famílias (Foucault, 2014, 125). Trata-se de uma nova posição da criança em relação à prática psiquiátrica, pondo em continuidade, ou antes, pondo em imobilidade a vida em torno da infância. Foucault é claro ao dizer que é pela infância que a psiquiatria veio a se apropriar do adulto e da totalidade do adulto, a infância como uma armadilha de pegar os

poder que se exerce não é disciplinar, a família opera como a dobradiça, o ponto de desencadeamento absolutamente indispensável ao funcionamento de todos os sistemas disciplinares. Na medida em que o indivíduo é rejeitado sucessivamente de um certo número de sistemas disciplinares, como inadmissível, indisciplinável, ineducável, ele é rejeitado para a família. (Foucault, 2003, 81-83) 
adultos, valendo-se, dentre outros, da ideia de desenvolvimento normativo (Foucault, 2014, 264-271) e da noção de estado.

Ora, este jogo em torno da (in)dizibilidade é central na discussão do direito, da justiça, da infância e da monstruosidade.

Segundo Benveniste, as línguas indo-europeias, em sua variedade, não têm um termo comum para designar o direito, mas os elementos remetem todos ao conceito de ordem, de ordenação do universo como fundamento, tanto religioso quanto moral, de garantia para que a sociedade não retorne ao caos (Benveniste, 1974, 100), numa pluralidade de níveis: o direito familiar (Themis ${ }^{7}$ ) e o direito entre as famílias da tribo (Dikê). A diferença entre estes níveis é que a raiz de Dikê significa mostrar pela palavra, ou dizer, sempre com autoridade, porque prescreve a fórmula da norma aos casos em que aplicáveis (Benveniste, 1974, 107-110).

O direito era, assim, considerado como um corpo de fórmulas e o exercício do direito como uma técnica, não como ciência que admitisse invenção. Era um conjunto de ditos, de receitas a conhecer, sendo o papel do juiz o de mostrar a medida que se impõe em tal ou qual litígio. Foi pelas mudanças linguísticas e nas instituições que o direito deixa de ser esse aparato técnico e se constitui em noções morais, derivando de Dikê o adjetivo dikaios e de ius, a noção de iustitia. A substituição paulatina do termo ius por directum, aquilo que é direito, por oposição ao que é perverso, - tão próximo ao nosso discurso da anormalidade - remete a esta transformação em instituição (Benveniste, 1974, 131).

Mas havia um terceiro nível que nos interessa na discussão sobre a vinculação do indizível à infância: o do direito divino. O termo que o designa é fas, em oposição a ius. Fas remete a falar ${ }^{8}$ e seu sentido emerge justamente do significado de infans, aquele que não fala. Fala aquele que, pela primeira vez, emite uma palavra dotada de sentido: tem-se em mente a palavra como manifestação da linguagem, como emanação da pessoa humana. Quando a criança fala, iam fatur, retém-se não o que diz, mas a manifestação de uma faculdade impessoal comum a todos os seres

\footnotetext{
7 Themis é de origem divina e prescreve os direitos e deveres de cada um sob a autoridade do chefe do genos, seja na vida cotidiana, seja nas circunstâncias excepcionais da aliança, casamento ou combate (Benveniste, 1974, 102)

${ }^{8}$ Daí fabula (conversação, peça dialogada, lenda; fama (renomado) e seu contrário, infamis, que não é bem renomado.
} 
a infância e o (in)dizível: poder ubuesco, resistência e a possibilidade da justiça

humanos: o ser capaz de palavra. É por este poder estranho, extra-humano, da palavra, a partir de seu primeiro despertar na criança até as manifestações coletivas (vox populi), que se exprime a voz divina. De fas deriva phatos, que remete também ao limite, a um limite que não foi fixado pela enunciação divina, também uma palavra variada, ilimitada, proferida por um monstro (em Hesíodo) (Benveniste, 1974, 133-142).

Num outro contexto, tratando dos termos relativos aos signos e aos presságios religiosos, Benveniste ensina que monstrum deriva de monstrare (ensinar um determinado comportamento, prescrever a via a seguir) - numa clara aproximação com a Dikê -, devendo ser compreendido como um conselho, uma advertência dada pelos deuses, que se exprimem por signos que confundem o entendimento humano (Benveniste, 1974, 257). Os monstros, assim, tal como a infância, remetem ao limite do humano, são expressão de um poder estranho e extra-humano, do signo e da palavra e de suas faltas.

Esta tensão em torno do dizer e do indizível, da própria instituição do direito, revela, como aponta Bourdieu, uma disputa de forças, que tanto tem um efeito de assistência e de licitação como de fechamento e de desapossamento (Bourdieu, 1981, $4)$.

Trata-se, portanto, de analisar esses limites. Ora, para Foucault, a crítica é a análise dos limites e a reflexão sobre os mesmos, situando-se nas fronteiras, perguntando-nos daquilo que nos é dado como universal necessário, obrigatório, e problematizando qual é a parte do que é singular, contingente e devido às constrições arbitrárias. Cuida-se, assim, de uma tarefa de transformar a crítica exercida na forma de limitação necessária em uma crítica prática na forma de transposição (franchisement) possível, como pesquisa histórica através dos acontecimentos que nos levam a nos constituir, a nos reconhecer como sujeitos do que fazemos, pensamos, dizemos (Foucault, 1994, 573-575). Portanto, uma crítica que não virá para reencontrar essa pertinência, mas para transpô-la, no que, assim, expressa o exercício do pensamento pela exterioridade. 
Conforme expusemos alhures (Melo, prelo), Foucault trabalha com uma dupla indizibilidade nesta produtividade do anormal, de que a infância é emblemática.

Uma, mais explícita e trabalhada na obra de Foucault, é do monstro como exceção à lei, princípio de inteligibilidade de todas as formas de anomalia, que combina o impossível da lei biológica com o proibido da lei jurídica, que contradiz a lei numa infração levada ao limite máximo, a tal ponto que a deixa sem voz (Foucault, 2014, 47-48), porque introduz no coração da lei a indeterminação que o direito nas suas operações deve continuamente ocultar para poder funcionar (Nuzzo, 2018, 252). Nuzzo fala aqui de uma dimensão excedente do monstro, pelo fato de que nele se constitui o ponto de emergência de um conflito, de um desencontro, tanto sob o plano do discurso quanto sobre o plano das tecnologias de poder, em que a transgressão da lei leva-a a seu limite (Nuzzo, 2018, 246-250).

Mas há outra indizibilidade, institucional: a do poder que se manifesta como terror ubuesco, incontornável, inevitável (Foucault, 2014, 12-13), grotesco, que fala a linguagem do medo, infantil, desqualificando quem fala - no caso, o médicopsiquiatra de sua condição de cientista (Foucault, 2014, 30-31) -, mas também o próprio tribunal de menores que toma o exame como peça central, na costura, embora estranha e ridícula, da instituição judiciária com o saber médico (Foucault, 2014, 34-36).

Neste sentido, esse poder é monstruoso na medida em que explicita a indiferença originária entre violência e direito: a linguagem do medo de uma fala que não se sustenta senão por essa espada ubuesca, que, pondo-se fora da lei, corre o risco de voltar a lei contra si (Nuzzo, 2018, 248-250).

É uma linguagem que vai ao seu limite e que procura se apoiar em outro para se sustentar e não perder seu emblema de lei.

Olhar essa manifestação como monstruosa implica reconhecer no monstro também uma função crítica, porque, como diz Nuzzo, essa figura permite descentrar ainda uma vez o discurso filosófico-jurídico da modernidade, dessubjetivar o sujeito-substância-verdade, colocar em evidência as relações entre 
a infância e o (in)dizível: poder ubuesco, resistência e a possibilidade da justiça

verdade e poder, interrogar o poder não apenas sobre sua origem, sua legitimação, mas também sobre suas formas e funcionamento (Nuzzo, 2018, 14-16).

No entanto, na releitura que Gil faz da análise foucaultiana de "Las meninas", em "A palavra e as coisas", a partir da figura monstruosa do anão, se o monstro nega as leis, ele surge como aquilo que é preciso negar para que se reinstaure o reino da representação (Gil, 2006, 63). Se o monstro se constitui numa espécie de operador 'quase-conceitual' que, embora inquietando a razão, permite convencer que a existência do homem, sua 'normalidade', é produto de uma necessidade (GIL, 2006, 18-19), a problematização da indizibilidade ubuesca implica uma transposição, ela também monstruosa, que desperte fascínio pelo que expressa de potencial transformador: situando-se numa zona de indiscernibilidade entre o devir-outro e o caos, ele pode aparecer como um foco atrativo de saúde e de vida, rodeado por regiões mórbidas ou mortíferas (Gil, 2006, 125-126). Ela é resistência.

\section{poder ubuesco e resistência kynica.}

Retomamos a contextualização do debate foucaultiano em torno da pertinência entre verdade e justiça. Acompanhamos a passagem da busca retrospectiva da verdade dizível pelo testemunho, no inquérito, com enfoque no discurso, às técnicas de individualização e de diferenciação normativa e normalizadora na sociedade disciplinar, pelo exame, em que o dizível se desloca para as práticas sociais. Vimos, então, como, em "Os anormais", a problematização se transpõe para os limites dessa dizibilidade e analisamos, a partir da figura monstruosa do incorrigível que tem na indizibilidade de sua indeterminação o modo operatório do poder ubuesco médico-judiciário que, em nome do desenvolvimento normativo na infância, tautologicamente reafirma sua necessidade. Tomamos, então, esta indizibilidade como eixo analítico entre direito, infância e monstruosidade para enfatizar sua dimensão crítica.

As perguntas que nos mobilizam, aqui, são: que transposições heterotópicas ${ }^{9}$ e paródicas dessas monstruosidades ubuescas da lei e do poder e de suas

\footnotetext{
${ }_{9}^{9}$ Para Foucault, as heterotopias inquietam porque minam secretamente a linguagem, arruínam de antemão a sintaxe. É por isso que as utopias permitem as fábulas e os discursos, ao passo que as heterotopias param as palavras sobre si mesmas, contestam, desde a raiz, toda possibilidade de
} 
indizibilidades podemos ver nos estudos em torno do kynismos? Quais estratégias de resistência são possíveis? Como isto se expressa em crianças e adolescentes?

Vemos no estudo foucaultiano da parresía cínica um claro exercício crítico em relação à monstruosidade do poder ubuesco.

A parresía cínica, para Foucault, é uma espécie de extrapolação em vez de exterioridade (Foucault, 2011a, 200) dessa pertinência entre o enunciado da verdade e a prática da justiça.

Sua “indizibilidade" se manifesta em não dar primazia ao discurso, mas a ser um caminho breve para a virtude, sem discurso (Foucault, 2011a, 184), que encontra seu instrumento, seu lugar, seu ponto de emergência na própria vida daquele que deve assim manifestar a verdade ou dizer a verdade, sob a forma de uma manifestação de existência: a forma de vida não apenas como testemunho da verdade (Foucault, 2011a, 191), mas exercício do escândalo da verdade em e por sua vida (Foucault, 2011a, 152).

Como sustenta Sloterdijk, com Diógenes começa na filosofia europeia a resistência ao jogo viciado do "discurso". Desesperadamente alegre, ele se defende contra a "verbalização do universalismo", "[...] fareja na 'teoria' a trapaça das abstrações idealistas e a insipidez esquizoide de um pensamento cerebral" que separa teoria e prática, pessoa e coisa, criando, subversivamente, um Esclarecimento rudimentar, no que o pensador alemão identifica um primeiro "materialismo dialético" autêntico, que era também um existencialismo. É neste sentido que incorporar uma doutrina significa fazer de si seu médium, e não como ocorre entre os moralistas, guiar a ação estritamente pelo ideal. “Atentando para o que pode ser encarnado, mantemo-nos ao abrigo da demagogia moral e do terror das abstrações radicais, das abstrações não vivenciáveis" (Sloterdikj, 2012, 153-154).

Tal como Ubu, o cínico também é grotesco. Mas ele o é como espelho quebrado para a filosofia (antiga como contemporânea), em que todo filósofo pode e deve se reconhecer, no qual ele pode e deve reconhecer a própria imagem da filosofia. Nesse espelho, contudo, ele percebe como que uma careta, uma

gramática; elas desatam os mitos e golpeiam de esterilidade o lirismo das frases. (Foucault, 2015b, 9-10) 
a infância e o (in)dizível: poder ubuesco, resistência e a possibilidade da justiça

deformação violenta, feia, sem graça, na qual ele não poderia em hipótese alguma se reconhecer nem reconhecer a filosofia. No entanto, se o poder anormalizador ubuesco é um discurso do medo, desqualificado porque dissociado daquilo que o fundamenta, o paradoxo do cinismo o situa no que Foucault descreve como uma história, ou pré-história, da coragem da verdade (Foucault, 2011a, 204-205).

É uma forma de coragem de dupla maneira. Uma, no sentido de que o parresiasta se arrisca a desfazer, a deslindar essa relação com o outro que tornou possível precisamente seu discurso, mas que também, no limite, põe em risco a própria existência daquele que fala, se em todo caso seu interlocutor tem um poder sobre aquele que fala e se não pode suportar a verdade que este lhe diz (Foucault, 2011a, 11-15). A forma de o fazer é pegar a moeda da aléthes bíos para fazer aparecer, por passagem ao limite, sem ruptura, uma vida que é precisamente o contrário do que era reconhecido tradicionalmente como a verdadeira vida, carateando-a (Foucault, 2011a, 200), mas também mudando o costume, rompendo com ele, quebrando as regras, os hábitos, as convenções e as leis (Foucault, 2011a, 208).

Neste sentido, se o poder ubuesco é indigno porque paródico da cidade justa ao conferir um poder incontrolado à ciência, por meio do aparelho da justiça (Foucault, 2014, 13), a parresía cínica é uma reversão emblemática do poder: o cínico é o rei, o antirrei, rei dissimulado, rei das sombras, rei miserável e derrisório invertendo novamente Ubu com seu poder ridículo -, numa forma particular de militantismo: aberto, universal, agressivo, militantismo no mundo contra o mundo (Foucault, 2011a, 250-251), que luta pelos outros e contra os inimigos, tomando a forma da resistência, do despojamento, da provação perpétua de si sobre si, mas também da luta na humanidade em relação à humanidade, pela humanidade inteira (Foucault, 2011a, 247), numa reforma de um mundo inteiro, por uma catástase do mundo (Foucault, 2011a, 278-279).

Para Foucault, se a resistência obriga, sob seu efeito, que as relações de poder mudem (Foucault, 1994, IV , 741), não há instauração da verdade sem uma posição essencial da alteridade. Portanto, se a verdade nunca é a mesma, só pode haver verdade na forma do mundo outro e da vida outra (Foucault, 2011a, 298), marcada, portando, por relações de diferenciação, de criação, de inovação (Foucault, 1994, IV, 
739) (ou iniciação, diria Lyotard), mas, também, por um campo político em que não tenha lugar a indiferença entre os sujeitos falantes, única condição da verdade poder ser dita (Foucault, 2011a, 41).

Na mesma linha, Sloterdijk afirma que, a partir do instante em que a filosofia - ou a política, ou o direito - não é capaz de viver o que ela diz senão de modo hipócrita, é preciso insolência para dizer o que se vive. Numa cultura em que os idealismos empedernidos fazem da mentira a forma de vida, o processo da verdade depende da existência de pessoas suficientemente agressivas e livres ("descaradas") para dizer a verdade. Agressividade produtiva, intrepidez diante do inimigo: “corajoso, ousado, vivo, destemido, indomado, ávido” (Sloterdijk, 2012, 154-155).

O pensador alemão vai mais além, entendendo que, se Platão e Aristóteles são pensadores que se situam do lado dos senhores, Diógenes opõe uma reflexão plebeia (Sloterdijk, 2012, 156-157). Aquele que detém o poder pode dar a si mesmo liberdade. O poder dos de baixo se manifesta individualmente na forma dessa insolência que constitui o cerne da força do kynismos. Com ela, os desfavorecidos podem antecipar a sua própria soberania (Sloterdijk, 2012, 165), insolente e irrisória ao levar às ruas o que há de baixo, de discriminado, de privado: isto, para Sloterdijk, significa subversão (Sloterdijk, 2012, 159).

A segunda maneira da coragem, para Foucault, é outra inversão de Ubu. Enquanto este precisa da dobra para falar por outro, o poder científico que se acopla ao poder judiciário, parodiando a cidade justa, a parresía cínica, como toda parresía, procura dobrar o interlocutor para que ele aceite o jogo da parresía, mostrando a sua grandeza de alma aceitando que lhe digam a verdade. Diversamente da linguagem do medo do psiquiatra no Judiciário, a parresía coloca em cena a exigência de coragem do interlocutor (do político, do gestor, do juiz, do técnico...) que aceita receber como verdadeira a verdade ferina que ouve (Foucault, 2011a, 13) para que ele também seja capaz de uma diferenciação ética, de uma elaboração do limite de seu poder e de se conduzir em conformidade com essa verdade (Foucault, 2011a, 54).

Ganha destaque, assim, a contraposição do dobramento mesclado ubuesco com a afirmação cínica de vida sem mistura, sem vínculo, sem dependência em 
a infância e o (in)dizível: poder ubuesco, resistência e a possibilidade da justiça

relação ao que podia lhe ser alheio (Foucault, 2011a, 225), porque afirmativa da alteridade.

Poderíamos ver ainda uma inversão a mais, embora não explicitamente tematizada por Foucault em sua análise do cinismo, mas que decorre de suas análises e que interessa particularmente ao tema da infância.

Se o poder ubuesco tinha a criança como seu ponto de incidência privilegiado, como vimos no complexo tutelar descrito por Donzelot, a parresía cínica é a reversão do lugar simbólico da criança na sociedade.

Cambiano recorda que, no enigma da esfinge decifrado por Édipo, a criança, como quadrúpede, está muito próxima do animal (Cambiano, 1994, 77) e, como recorda Aristóteles, "ninguém optaria por viver durante toda a vida com a razão (dianoia) de uma criança". No entanto, era precisamente para uma posição deste gênero que pareciam convergir os cínicos mais radicais, sendo um de seus pressupostos o abandono da aplicação metafórica das idades da vida humana, adotando uma deliberada regressão à infância, paralela a um retorno da cultura para a natureza (Cambiano, 1994, 99; Laertios, 1987, 161).

Se os conceitos de inocência, espontaneidade e simplicidade da criança não pareciam estar muito difundidos na mentalidade comum grega, histórias de Diógenes revelam uma inversão deste ponto de vista, a recusa da cidade e das necessidades artificiais por ela geradas para se voltar apenas às funções essenciais determinadas pela natureza. Por isso que, para o cinismo, a par da criança, eram os animais - estes sim invocados por Foucault - que serviam de modelo para se ser um verdadeiro homem (Cambiano, 1994, 99).

Cambiano entende, deste modo, que, no cinismo, elaborava-se uma imagem positiva da criança: havia ali um modo de ensinar o adulto, corrompido pela vida das cidades, a voltar a ser criança, um ensinamento igualmente adotado pelos estóicos (Cambiano, 1994, 100).

Sloterdijk acompanha tal entendimento. Para ele, o exemplo de encarnar conscientemente sua força, com presença de espírito, que crie uma realidade que podemos, no melhor dos casos, combater, mas não negar, provém das crianças. Crianças brincando em grupo são muitas vezes boas escolas de Esclarecimento, 
porque treinam a dizer "e daí?", de modo natural. Esse seria o exercício mais duro para os homens completamente socializados: dizer não sempre no momento oportuno. A capacidade plenamente desenvolvida de dizer não é, por sua vez, o único pano de fundo que garante a validez do sim, e apenas os dois juntos definem o perfil de uma liberdade real (Sloterdijk, 2012, 165).

Por isso, para o pensador alemão, é preciso que o filósofo dê uma chance à criança que há nele, que "ainda não entende" todas essas coisas, porque aquele que “ainda não entende" pode, talvez, formular as questões certas (Sloterdijk, 2012, 188).

Mas esta chance que se há de dar é num registro diverso de nossa tradição. Afinal, como o próprio Foucault salientara numa etapa anterior de seu pensamento, o grande tema do Olhar-Infância pode ser traçado de Pestalozzi aos Bildungsromane. Como ele lembra,

A infância, a juventude das coisas e dos homens eram carregadas de um poder ambíguo: dizer o nascimento da verdade, mas também colocar à prova a verdade tardiva dos homens, retificá-la, aproximála de sua nudez... Incansavelmente em cada criança as coisas repetem sua juventude, o mundo retoma contato com sua forma natal: não é nunca adulto para quem o vê pela primeira vez. O olho pode se abrir ao nível das coisas e das idades, de todos os sentidos e saberes. (Foucault, 2015c, 97-98)

A primazia filosófica do olhar e de seus temas correlatos da luz, da clareza, sobretudo na linguagem ${ }^{10}$, foram examinados por Foucault em seu duplo papel de fundação do indivíduo. De um lado, em sua qualidade irredutível, tornando possível organizar em torno dele uma linguagem racional - como, ainda, a promessa de unidade serena de uma subjetividade que triunfaria em si, estando por ele e através dele inteiramente constituída (Foucault, 1994, I, 244). De outro lado, a possibilidade de uma experiência clínica (Foucault, 2015c, 10-12), que, como vimos, foi um dos modos fundamentais de imiscuição da medicina na justiça para constituição do poder ubuesco.

Neste contexto, esta subversão da indizibilidade do poder ubuesco passa igualmente por uma crítica dessa primazia filosófica do olhar. Para Foucault, com a morte de Deus e o vazio ontológico que ela deixou, dá-se a aparição ainda surda e

\footnotetext{
${ }^{10}$ Jay aponta o quanto a prevalência de metáforas visuais pode ser tomada como obstáculo ou uma ajuda para nosso conhecimento da realidade pela nítida correlação entre o voir (ver) tanto em savoir (saber) como pouvoir (poder) (Jay, 1993, 3)
} 
a infância e o (in)dizível: poder ubuesco, resistência e a possibilidade da justiça

tateante de uma forma de pensamento em que a interrogação sobre o limite se substitui à procura da totalidade e onde o gesto da transgressão substitui o movimento das contradições (Foucault, 1994, I, 248-249). É nessa experimentação do pensamento (e pela linguagem mesma) até os seus limites, que se dá a abertura que é a comunicação (Foucault, 1994, I, 243).

Para Sloterdijk, a crítica kynica recoloca a questão da comunicação por uma inversão da linguagem verbal, pautada no distanciamento da visão, à reflexão de uma fisionômica filosófica a partir de uma linguagem muda, lançando suas raízes até o domínio do pré-humano, do pré-racional, até a esfera do faro e da orientação animal. Para ele, é um campo em que todos os sentidos se encontram profundamente emaranhados, que chamam a uma competência perceptiva contra a devastação dos sentidos, que é o preço do progresso civilizatório.

Contra o distanciamento propugnado pelo processo civilizatório, mantendo os objetos diante de nós, o sentido fisionômico reclama a intimidade, não o distanciamento; um saber convivial, não objetivo; uma fala plural (Sloterdijk, 2012, 199)11. Esta filosofia fisionômica é, para o filósofo, integrante, porque não se seduz pelos "grandes problemas", mas vai ao encontro dos temas que se acham "embaixo", nas coisas da vida cotidiana, no que é supostamente de pouca importância, que não é digno de atenção, nas pequenezas (Sloterdijk, 2012, 201) ${ }^{12}$. Contra o cinismo dos meios da razão instrumental, porque se pauta nesse distanciamento do olhar, o kynismos se apresentaria como uma filosofia crítica e

11 Jay recorda que, para Freud, a civilização humana apenas começa quando os hominídeos levantam-se do solo, param de cheirar as regiões baixas de seus semelhantes e elevam a visão a uma posição de superioridade, com a concomitante repressão dos impulsos sexuais e agressivos e da radical separação das faculdades espirituais e mentais das funções baixas do corpo. A crítica à primazia do olhar, em Bataille, pode ser lida como uma demanda tática pela reversão desse fatal desenvolvimento humano. (Jay, 1993, 221-222).

$12 \mathrm{O}$ filósofo alude às crianças na fisionômica da boca amarga, dizendo que "muitas crianças a quem a vida iludiu, apresentam esses lábios amargamente fechados, dos quais é difícil arrancar algum assentimento por algo de bom. A desconfiança é a inteligência dos lesados", mas também na falta de noção por parte das crianças da negatividade de seus dejetos e que remete à possibilidade de elaboração de uma consciência da natureza que avalia de maneira positiva o lado animal do homem, sem nos isolar do baixo e do desagradável, assumindo que o homem é produtor de dejetos e não está em seu poder escolher ser de outro modo. Coloca em questão o repensar da utilidade do inútil, da produtividade do improdutivo, da positividade do negativo e da nossa competência para aquilo que é indesejado (Sloterdijk, 2012, 204; 214) 
irônica das supostas necessidades, na radiografia de sua desmedida e de seu princípio absurdo (Sloterdijk, 2012, 268).

Para Niehues-Pröbsting, o caráter subversivo do kynismos dá-se no contexto da antítese sofística entre nomos e physis, levando-a ao extremo para desprover a medida de uma referência divina ou humana, mas animal (Niehues-Pröbsting, 2016, 96) como estratégia limite para expor as fraquezas da polis e de suas instituições (Niehues-Pröbsting, 2016, 16). Essa animalidade, da qual se origina, segundo algumas hipóteses, o próprio termo kynismos (de Kyon, cachorro), aponta à plasticidade que nos permite, do caos de circunstâncias, opor liberdade de agir (Niehues-Pröbsting, 2016, 24-25).

Desta forma, para o pesquisador alemão, o kynismos antigo realiza de forma consequente e extremada a virada socrática da especulação da natureza para a problematização ética (Niehues-Pröbsting, 2016, 191). A parresía cínica é o que faz com que esta problematização ética ganhe coloração política, na medida em que afronta o que é convencional (Niehues-Pröbsting, 2016, 207), assumindo sua potência pela conjugação com a comédia (Niehues-Pröbsting, 2016, 218): é o riso que permite apequenar, enfraquecer e desqualificar aquele que se apresenta como grande, forte e inteligente, mas também como reação a um apoucamento e desvalorização operado por um oponente.

A potência do riso, que Foucault invocara, mas pouco explorara nos estudos anteriores sobre verdade e justiça, reaparece no kynismos ${ }^{13}$ para servir como meio de afirmação de si pelo caminho do distanciamento e da distância. O riso tanto pode ser um meio de nos liberar da pressão ou do perigo - afinal só conseguimos rir quando os destronamos- como um meio para pressionar, para criar insegurança no adversário, mas de forma cautelosa, conjurando nossas travessuras, não só para não perder a distância que nos protege, como para aumentá-la (Niehues-Pröbsting, 2016, 222-223). É por este poder desestabilizador que se via no kynismos a

13 Em "A verdade e as formas jurídicas", Foucault invoca o Nietzsche d" "A Gaia Ciência", para afirmar o conhecimento como jogo de afrontamento, de luta e de apaziguamento entre instintos albergados pelo Intelligere: ridere, rir, lugere, deplorar, e detestari, detestar. Essas três paixões, para ele, têm em comum o fato de serem uma maneira não de se aproximar do objeto nem de se identificar com ele, mas, ao contrário, de conservar o objeto à distância, de se diferenciar dele ou de se colocar em ruptura com ele, de se proteger dele pelo riso, desvalorizá-lo pela deploração, afastá-lo e, eventualmente, destruí-lo pelo ódio, numa maldade radical do conhecimento (Foucault, 1996, 21) 
a infância e o (in)dizível: poder ubuesco, resistência e a possibilidade da justiça

possibilidade de inversão e de subversão e que fazia pensadores antigos, como Dion Chrysóstomos, temer o desprezo de crianças aos seus professores (NiehuesPröbsting , 2016, 13-14) se rompida a diferenciação de graus de inteligências para justificar a direção da multidão estúpida pela casta inteligente, criticada por Jacotot (Rancière, 1987, 218).

A infância exerceria, assim, a mesma função de alteração da efígie da moeda da aléthes bíos, fazendo aparecer, por passagem ao limite, sem ruptura, simplesmente empurrando esses temas até seu ponto extremo, uma vida que é precisamente o contrário do que era reconhecido tradicionalmente como a verdadeira vida. É uma trilha com pontos de conexão com a invocação da infância para a crítica da racionalidade moderna, como em Benjamin (Stüssi, 1977), em Lyotard (Lyotard, 1991; 1998; 2005), em Deleuze-Guattari (Deleuze-Guattari, 2012) e da exaltação do progresso - ou do desenvolvimento, da evolução - como o valor regente da vida (Melo, prelo). O kynismos como careta da verdadeira vida, a infância como careta da completude e da plenitude adultas, da pretensa equivalência entre língua e discurso (Agamben, 2002, 14-15).

Foucault procura realizar, assim, um tríplice deslocamento teórico - do tema do conhecimento para o tema da veridicção, do tema da dominação para o tema da governamentalidade, do tema do indivíduo para o tema das práticas de si - em que se pode estudar as relações entre verdade, poder e sujeito, sem nunca reduzi-las umas às outras (Foucault, 2011a, 9-10). Procuramos ver estas transposições em torno do tema da (in)dizibilidade e da pertinência entre verdade e justiça e as práticas resistentes por crianças e adolescentes a partir do inquérito, do exame e das práticas kynicas.

Estes temas são ínsitos ao debate que caracteriza o ubuesco - essa indiferença originária entre violência e direito, em que, chegando-se ao limite da lei, pondo-se fora da lei, corre-se o risco de voltar a lei contra si mesma (Nuzzo, 2018, 250) e que Nuzzo, como nós, encontra ressonância na análise de Derrida sobre a justiça, sobre os direitos humanos como apelo ético à resistência. 


\section{para concluir: a criança e a possibilidade da justiça}

Acompanhamos os deslocamentos do debate em torno da pertinência entre verdade e justiça, do testemunho ao exame e aos limites da indizibilidade, em transposições críticas do poder ubuesco à prática resistente kynica. Vimos, em todos estes momentos, a centralidade da infância. Cuidaremos, aqui, de repensar o (in)dizível pela criança e a possibilidade de justiça

Derrida tratará igualmente do limite da indizibilidade do poder ao se perguntar como distinguir entre a força da lei, força de lei, da violência que sempre julgamos injusta. Que diferença há entre, de um lado, a força que pode ser justa, de todo modo julgada legítima e, de outro lado, a violência que se julga sempre injusta? (Derrida, 1994, 18).

Ele lembra Montaigne, que atribui um fundamento místico de autoridade às leis, distinguindo as leis da justiça. As leis não são justas enquanto leis. Não as obedecemos porque elas são justas, mas porque têm autoridade. Nessa linha, Derrida realiza uma crítica da ideologia jurídica, entendendo que o surgimento mesmo da justiça e do direito, o momento instituidor, fundador e justificador do direito, implica uma força performativa, i.e., sempre uma força interpretativa e um chamado à crença: seu momento de fundação ou de instituição mesmo não é um momento inscrito no tecido homogêneo da história já que ele o rasga com uma decisão, numa violência performativa que é interpretativa.

Nesse sentido, o discurso justificador não pode nem deve assegurar o papel de metalinguagem com relação à performatividade da linguagem instituidora ou à sua interpretação dominante. É aí, para Derrida, que o discurso reencontra seu limite, no místico, num silêncio murado na estrutura violenta do ato fundador. Murado, emparedado, porque esse silêncio não é exterior à linguagem (Derrida, 1994, 33), mas, como em Foucault, é um silêncio que procura ocultar para poder funcionar.

Nessa estrutura, o direito é essencialmente passível de desconstrução, seja porque ele é fundado, i.e., construído sobre camadas textuais interpretáveis e transformáveis, seja porque seu fundamento último por definição não é fundado. É isso que torna possível a desconstrução, ou ao menos, o exercício de uma 
a infância e o (in)dizível: poder ubuesco, resistência e a possibilidade da justiça

desconstrução que procede do fundo das questões do direito e ao sujeito de direito, como uma oportunidade política (Derrida, 1994,35) em que se pode recolocar essa questão da (im)pertinência ético-política da justiça e da verdade, em outros termos.

Para Derrida, essa relação entre direito e justiça é aporética, porque se o direito é elemento do cálculo, a justiça é incalculável, ela exige que se calcule com o incalculável, em que a decisão entre o justo e o injusto não é assegurado por uma regra (Derrida, 1994, 38).

Com efeito, numa linha com pontos de conexão à integração judicial do direito, Derrida sustenta que, para ser justa, a decisão de um juiz deve não apenas seguir uma regra de direito ou uma lei geral, mas ela deve assumi-la, aprová-la, confirmar seu valor, por um ato de interpretação reinstaurador como se, no limite, a lei não existisse antes, como se o juiz a inventasse ele mesmo a cada caso (Derrida, $1994,50-51)$.

Para que uma decisão seja justa e responsável, é preciso que em seu momento oportuno, se há um, ela seja ao mesmo tempo regrada e sem regra, conservadora da lei e suficiente desconstrutiva ou suspensiva da lei para dever a cada caso reinventála, rejustificá-la, reinventá-la ao menos na reafirmação ou confirmação nova e livre de seu princípio. Cada caso é outro, cada decisão é diferente e requer uma interpretação absolutamente única, que nenhuma regra existente e codificada pode nem deve absolutamente garantir (Derrida, 1994, 51).

Desse paradoxo, segue-se que a qualquer momento não se pode dizer pretensamente que uma decisão seja justa, puramente justa, nem de alguém que ele seja justo ou que eu seja justo. No lugar de justo, pode-se dizer legal ou legítimo. Pois no fundamento ou na instituição desse direito, o mesmo problema da justiça teria sido colocado, violentamente resolvido, isto é, enterrado, dissimulado, recalcado (Derrida, 1994, 52).

Este é um momento de suspensão, angustiante, que abre também o intervalo de espaçamento em que as transformações, até mesmo as revoluções jurídicopolíticas tiveram lugar. Para Derrida, esta epokhé não pode ser motivada, não pode encontrar seu movimento e seu élan senão na exigência de um acréscimo, de um suplemento de justiça, portanto na experiência de uma inadequação ou de uma 
incalculável desproporção. Portanto, não de uma renovada fundação ou adequação à verdade, mas como crítica, como desconstrução, onde encontra sua força, seu movimento, ou sua motivação nesse chamado sempre insatisfeito, de justiça, da possibilidade de justiça (Derrida, 1994, 46).

Por isso, para Derrida, a desconstrução é a justiça (Derrida, 1994, 35), notadamente porque não há justiça sem essa posição de alteridade, de se dirigir a outro na língua de outro como a condição de toda justiça possível. A violência do direito se apresenta quando parece implicar um elemento de universalidade, o recurso ao terceiro que suspende a unilateralidade ou a singularidade dos idiomas, num diálogo com a forma lida por Foucault ao discorrer sobre a justiça popular (Foucault, 1994, II, 340).

A violência dessa injustiça, que consiste em julgar aqueles que não entendem o idioma no qual se pretende que a justiça seja feita, supõe que o outro, a vítima da injustiça da língua, esta que supõe todas as outras, seja capaz de uma língua em geral (Derrida, 1994, 41).

Aqui aparece a criança, com a necessidade de desconstruir as partições que instituem o sujeito humano (de preferência e paradigmaticamente o homem adulto, antes que a mulher, a criança e o animal) como medida do justo e do injusto - a distribuição de lugares a que se refere Rancière (Rancière, 2012, 119). Mais ainda, aqui aparece a responsabilidade diante de uma herança que remete sempre a justiça a singularidades, à singularidade do outro, apesar ou em razão mesmo de sua pretensão de universalidade (Derrida, 1994, 44). Universalidade que, novamente com Rancière, há de ser pensada como igualdade, como uma potência da qual convêm verificar o efeito (RANCIÈRE, 2012, 95). Uma igualdade de princípio dos seres falantes (Rancière, 2012,67) - repensando o ato de fala de modo a entender o que é feito e por certos tipos de representações (enactments) corporais como parte de uma performatividade plural e corporizada marcada pela dependência e resistência (Butler, 2015, 18) -, numa verificação sempre polêmica do que dela resulta (Rancière, 2012, 116).

Deste modo, se o poder ubuesco é normalizador, essa vinculação da justiça com singularidade, partindo a medida do justo e do injusto, remete efetivamente à 
a infância e o (in)dizível: poder ubuesco, resistência e a possibilidade da justiça

diferenciação ética, numa escuta que se dá na tensão discursiva ou além do discurso, na singularidade de manifestação de vida.

Não numa verdade-demonstração, de busca de pertinência entre verdade e justiça, mas numa verdade-acontecimento, que não é constatada, mas suscitada, perseguida, caçada, cercada, que se provoca por rituais, que se capta por artimanhas, que se toma de acordo com as ocasiões, de acordo com as estratégias, numa relação de choque, de trovão e de relâmpago, numa relação de poder (Foucault, 2003, 237). Para Foucault, é nesta cesura, nessa diferença, nessa dramaticidade de um acontecimento espetáculo que se dá abertura a uma distinta cultura de si, porque assoma como atitude crítica, na qual o Outro também é requerido, não para livrar-se do perigo, mas para estar coligadamente alerta, resistente, operando a vida na sua relação consigo (Foucault, 2010, 164).

A leitura foucaultiana de direitos humanos é expressão parresiástica desta coragem de verdade resistente, uma atitude crítico-reflexiva sobre o hoje como diferença na história e como motivo para uma tarefa filosófica particular, que não só implica uma prática de se definir as formas nas quais a relação consigo pode eventualmente se transformar, num modo de subjetivação outro (Foucault, 2011b, 321), mas que tem igualmente apelo universal ao se apresentar como um "[...] dever da cidadania internacional de sempre fazer valer aos olhos e aos ouvidos dos governos a infelicidade dos homens" (Foucault, 1994, IV, 355), ganhando uma dimensão coletiva e coligativa. A novidade desse direito, segundo Fonseca, radica justamente em sua expressão ética, plural, resistente, à governamentalidade e à normalização (Fonseca, 2002, 268) ${ }^{14}$.

É neste exercício de exterioridade, ao colocar-se para fora das margens do discurso universalizante, do discurso adulto, racional, e abrindo-se ao que o saber disciplinar reputaria como toda uma teratologia do saber, é neste espaço de uma exterioridade selvagem, que, para Foucault, se abriria a possibilidade de dizer o verdadeiro (Foucault, 2014, 34): um verdadeiro homológico, quase erótico, que ganha, diríamos, densidade, na medida em que se revela como um exercício de

\footnotetext{
${ }^{14}$ Na leitura de Golder, tratar-se-ia de pensar uma política de direitos anti-fundacionalista, não fundada antropologicamente, portanto o direito como criticamente engajado (Golder, 2015, 6).
} 
amizade, de afeto, de vínculo intenso com o gênero humano inteiro, por um mundo outro (Foucault, 2011a, 265).

A justiça, se é desconstrução, é porque, como vimos, demanda esta coragem do outro - e do outro governante como instituição - que escuta a singularidade desse levante, desses dizeres outros, arriscando as suas próprias certezas, seu próprio idioma, porque deve falar na linguagem desse outro, diferenciando-se a si mesmo, eticamente, neste processo.

Os direitos humanos se entrelaçam, assim, com essa dimensão ética, que Derrida traduz como justiça, igualmente invocada por Foucault nas práticas de resistência, como estratégia de majoração da potência de aparência no espaço público, de forma dissensual e diferencial, por outras possibilidades de subjetivação.

Longe do debate em torno de direitos positivos ou naturais, de direitos legais ou morais que anima a teoria jurídica dos direitos humanos, Foucault se aproxima mais de teorias realistas, como de Bobbio, enxergando nos direitos humanos uma função prática-estratégica de reivindicação (Bobbio, 1992, 10), assumindo seu relativismo por sua historicidade (Bobbio, 1992, 19).

Mas, conquanto não pretenda tampouco a busca de fundamentos ou de justificação (BOBBIO, 1992, 24), Foucault entende que, sim, os direitos fundamentais são um problema filosófico, de crítica, de problematização, como, com Butler, uma forma de virtude estabelecida mediante sua diferença diante de uma obediência acrítica com relação à autoridade, sempre situada e expressa por uma pergunta específica que surge em relação com uma forma específica de governo: “[...] como não ser governado dessa forma, em nome destes princípios, em vista destes objetivos, e por meio destes procedimentos, não desta forma, não para isso, não por eles" (Butler, 2001, p. 7-8).

Se a governamentalização é um movimento pelo qual se tratava, na realidade mesma de uma prática social, de sujeitar os indivíduos por meio de mecanismos de poder que invocam uma verdade, a crítica é o movimento pelo qual o sujeito se atribui o direito de interrogar a verdade acerca de seus efeitos de poder e ao poder acerca de seus discursos de verdade. Coloca-se em primeiro plano a reflexividade 
a infância e o (in)dizível: poder ubuesco, resistência e a possibilidade da justiça

da reivindicação. A crítica, para Foucault, será a arte da inservidão voluntária, da indocilidade reflexiva. Pôr em jogo a liberdade tem algo a ver com o que Foucault chama de virtude (Butler, 2001, 10-11) e é esta virtude que está no cerne da atribuição do direito de reivindicação de direitos.

É neste exercício da aporia da diferença que se dará a condição de abertura para a experiência da alteridade vivida por essas próprias crianças e adolescentes e, por conseguinte, da escuta parresiástica dessas linguagens singulares e das resistências possíveis na vulnerabilidade. Com tentativas outras de se estar próximo e, mais do que se escutar, de se encontrar.

\section{referências}

Agamben, Giorgio. Enfance et histoire. Paris: Payot, 2002.

Bobbio, Norberto. A era dos direitos. Rio de Janeiro, Campus, 1992a.

Bourdieu, Pierre. La représentation politique. Éléments pour une théorie du champ politique. Actes de la Recherche en Sciences Sociales. ano 1981,

Butler, Judith. Qué es la crítica? Un ensayo sobre la virtud en Foucault. Traducción de Marcelo Expósito e Joaquín Barriendos. 2001. Disponível em: http:/ / eipcp.net/transversal/0806/butler/es. Acesso em: 15 out. 2019.

Butler, Judith. Notes toward a performative theory of assembly. Cambridge, Massachusetts: Harvard University Press, 2015

Cambiano, Giuseppe. Tornar-se homem. In: Vernant, Jean-Pierre. O homem grego. Lisboa: Editorial Presença, 1994.

Costa, Jurandir Freire. Ordem médica e norma familiar. 4. ed. Rio de Janeiro: Graal, 1999.

Deleuze, Gilles; Guattari, Félix. Mil platôs. São Paulo: Editora 34, 2017. v. 4.

Derrida, Jacques. Force de loi. Le 'fondement mystique de l'autorité'. Paris: Galilée, 1994

Donzelot, Jacques. A polícia das famílias. 2. ed. Rio de Janeiro: Graal, 1986.

Ewald, François. L'État Providence. Paris: Éditions Grasset \& Fasquelle, 1986. E-book

Fonseca, Márcio Alves da. Michel Foucault e o direito. São Paulo: Max Limonad, 2002.

Foucault, Michel. Dits et écrits (Ditos e escritos). Paris: Gallimard, 1994. 4 v.

Foucault, Michel. A verdade e as formas jurídicas. Rio de Janeiro: PUC-NAU, 1996.

Foucault, Michel. Le pouvoir psychiatrique. Paris: Gallimard, 2003.

Foucault, Michel. Segurança, território, população. São Paulo: Martins Fontes, 2008.

Foucault, Michel. A hermenêutica do sujeito. São Paulo: Martins Fontes, 2010.

Foucault, Michel. A coragem da verdade. São Paulo: Martins Fontes, 2011a.

Foucault, Michel. O governo de si e dos outros. São Paulo: Martins Fontes, 2011 b.

Foucault, Michel. Os anormais. São Paulo: Martins Fontes, 2014.

Foucault, Michel. L'archéologie du pouvoir. Paris: Gallimard, 2015a

Foucault, Michel. Les mots et les choses. Une archéologie des sciences humaines. Paris: Gallimard, 2015b

Foucault, Michel. Naissance de la clinique. Paris: PUF, 2015c.

Gil, José. Monstros. Lisboa, Relógio d’água. 2006 
Golder, Ben. Foucault and the politics of rights. Stanford: Stanford University Press, 2015.

Jay, Martin. Downcast eyes. The denigration of vision in twentieth-century French thought. Berkeley, University of California Press, 1993

Laertios, Diogenes. Vidas e doutrinas dos filósofos ilustres. 2. ed. Brasília, DF: UNB, 1987.

Lyotard, Jean-François. A condição pós-moderna. 5. ed. Rio de Janeiro: José Olympio, 1998.

Lyotard, Jean-François. Le postmoderne expliqué aux enfants. Paris: Galilée, 2005.

Lyotard, Jean-François. Lectures d'enfance. Paris: Galilée, 1991.

Melo, Eduardo Rezende. Direito ao desenvolvimento: arqueologia de um dispositivo na subjetivação de crianças e adolescentes. São Paulo: Intermeios, no prelo

Niehues-Pröbsting, Heinrich. Der Kynismus des Diogenes und der Begriff des Zynismus. 2a edição, München, Suhrkamp Verlag, 2016

Nuzzo, Luciano. Il mostro di Foucault. Limite legge, eccedenza. Milano: Meltemi editore, 2018.

Rancière, Jacques. Au bords du politique. Paris: Gallimard, 2012.

Rancière, Jacques. Le maître ignorant. Cinq leçons sur l'émancipation intellectuelle. Paris: Fayard, 1987.

Sloterdikj, Peter. Crítica da razão cínica. 2. ed. São Paulo: Estação Liberdade, 2012.

Stüssi, Anna. Erinnerung an die Zufunft. Walter Benjamins "Berliner Kindheit um Neunzehnhundert". Göttingen: Vandenhoeck \& Ruprecht, 1977.

recebido em: 18.11 .2020

aprovado em: 21.12 .2020 